Sección Básica / Basic

Artículos de investigación / Research paper

\title{
Life table of Chrysoperla externa (Neuroptera: Chrysopidae) reared on Melanaphis sacchari (Hemiptera: Aphididae)
}

\author{
Tabla de vida de Chrysoperla externa (Neuroptera: Chrysopidae) alimentado con \\ Melanaphis sacchari (Hemiptera: Aphididae) \\ MARTÍN PALOMARES-PÉREZ1; TERESA DE JESÚS MOLINA-RUELAS; \\ MANUEL BRAVO-NÚÑEZ ${ }^{3}$; HUGO CESAR ARREDONDO-BERNAL ${ }^{4}$
}

\begin{abstract}
${ }^{1}$ Dr. Coordinador de investigador en control biológico de plagas agrícolas, Centro Nacional de Referencia de Control Biológico, km 1.5 Carretera TecománEstación FFCC, C. P. 28110, Colonia Tepeyac, Colima, México, mpalomares@colpos.mx, https://orcid.org/0000-0001-9474-5334. ${ }^{2}$ Estudiante, Universidad de Colima, Facultad de Ciencias Biológicas Agropecuarias, km 40 Carr. Manzanillo-Colima, Tecomán, Colima, México, molina teresa@ucol.mx, https:// orcid.org/0000-0002-1981-3883. ${ }^{3}$ Técnico, auxiliar de investigador, Centro Nacional de Referencia de Control Biológico, km 1.5 Carretera Tecomán-Estación FFCC, C. P. 28110, Colonia Tepeyac, Colima, México, menobravo81@gmail.com, https://orcid.org/0000-0003-4680-2343. ${ }^{4}$ M. C. Subdirector del CNRCB, Centro Nacional de Referencia de Control Biológico, km 1.5 Carretera Tecomán-Estación FFCC, C. P. 28110, Colonia Tepeyac, Colima, México, hcesar_64@ yahoo.com.mx, https://orcid.org/0000-0003-2146-3699.
\end{abstract}

Corresponding author: Martín Palomares-Pérez. Dr. Coordinador de investigador en control biológico de plagas agrícolas. Centro Nacional de Referencia de Control Biológico, km 1.5 Carretera Tecomán-Estación FFCC, C. P. 28110 , Colonia Tepeyac, Colima, México, https://orcid. org/0000-0001-9474-5334.

Suggested citation:

PALOMARES-PÉREZ, M.; MOLINARUELAS, T. J.; BRAVO-NÚÑEZ, M.; ARREDONDO-BERNAL, H. C. 2020. Life table of Chrysoperla externa (Neuroptera: Chrysopidae) reared on Melanaphis sacchari (Hemiptera: Aphididae). Revista Colombiana de Entomología 46 (1): e6831. https://doi. org/10.25100/socolen.v46i1.6831

Received: 25-Mar-2019

Accepted: 24-Nov-2019

Published: 31-Jul-2020

Revista Colombiana de Entomología

ISSN (Print): 0120-0488

ISSN (On line): 2665-4385

https://revistacolombianaentomologia.univalle.edu.co/

Open access

Publicadores / Publishers:

Sociedad Colombiana de Entomología SOCOLEN (Bogotá, D. C., Colombia) http://www.socolen.org.co Universidad del Valle (Cali, Colombia) http://www.univalle.edu.co/

(C) 2020 Sociedad Colombiana de Entomología - SOCOLEN y Universidad del Valle - Univalle
Abstract: Chrysoperla externa is a widely distributed and highly adaptable predatory insect. In order to evaluate its capacity as a natural enemy of the sugarcane aphid, Melanaphis sacchari, its life table when reared on $M$. sacchari was inferred. The biological cycle lasted an average of $29.5 \pm 6.2 \mathrm{~d}$ from egg to adult. The embryonic and larval period duration was 5.1 \pm 0.3 and $13.8 \pm 4.5 \mathrm{~d}$, respectively. The pupa stage was completed in $10.6 \pm 1.4 \mathrm{~d}$, whereas adults lived $63.5 \pm 26.7 \mathrm{~d}$ after eclosion. The mortality rate showed the highest values in the egg stage (qx $=0.17)$. The greatest survival rate appeared in the third instar $(93.7 \%)$. The period prior to reproduction was $6.5 \pm 3.1 \mathrm{~d}$. The average fecundity was $228.3 \pm 139.1$ eggs. The life table parameters were $\mathrm{Ro}=113.2, \mathrm{~T}=28.9, \mathrm{rm}=0.163$ and $\lambda=1.17$. According to the results, it is possible to infer that $C$. externa is capable of accomplishing its life cycle feeding only on M. sacchari.

Keywords: Biological control, life table parameters, predator, sugar cane, phytophagous, Melanaphis sacchari, Chrysoperla externa.

Resumen: Chrysoperla externa es un insecto depredador ampliamente distribuido y altamente adaptable a diferentes ambientes. Para evaluar su capacidad como enemigo natural de Melanaphis sacchari se realizaron estudios de su ciclo biológico y tabla de vida utilizando a esta plaga como alimento. El ciclo biológico duró en promedio $29,5 \pm 6,2 \mathrm{~d}$ de huevo a adulto. El periodo embrionario y la duración del estado larval fueron de 5,1 $\pm 0,3$ y 13,9 $\pm 4,5$ d, respectivamente. La pupa completó su ciclo en $10,6 \pm 1,4 \mathrm{~d}$ y los adultos vivieron $63,5 \pm$ $26,7 \mathrm{~d}$. La tasa de mortalidad registró los valores más altos en el estado de huevo $(\mathrm{qx}=0,17)$. La mayor viabilidad se presentó en la L3 (93,7 \%). El periodo de preoviposición fue 6,5 $\pm 3,1$ d y el promedio de huevos ovipositados por hembra fue de $228,3 \pm 139,1$. Las características reproductivas $\mathrm{Ro}=113,2, \mathrm{~T}=28,9, \mathrm{rm}=0,163$ y $\lambda=1,17$. De acuerdo con los resultados, es posible inferir que $C$. externa es capaz de completar su ciclo de vida alimentándose sólo de M. sacchari.

Palabras clave: Control biológico, parámetros tabla de vida, depredador, caña de azúcar, fitófago, Melanaphis sacchari, Chrysoperla externa.

\section{Introduction}

Lacewings of the genus Chrysoperla (Neuroptera: Chrysopidae) are some of the most important and frequently used natural enemies in biological control of agricultural pests (Chang et al. 2000; Miller et al. 2004). Chrysoperla externa (Hagen, 1861) is a predator with a high degree of adaptability to different climates; it allows this species to have a wide geographical distribution (Gitirana et al. 2001). Its wide prey range, including soft-bodied insects such as aphids, whiteflies, and thrips, allows for its use in many biological control programs (Guarín 2003). The predatory potential of the Chrysopidae family increases with their size during the larval stage (VelázquezGrisales 2004; Loera et al. 2001). Adults feed on nectar, pollen or honey produced by insects (Loera et al. 2001). They are easy to breed in laboratories (Cardoso and Lazzari 2003). 
In order to work with a natural enemy, either a predator or a parasitoid, in a biological control program, it is important to know about its biology. This information is basic and necessary in order to implement it in the integrated pest management programs (Salamanca Bastidas et al. 2010).

Therefore, considering the potential of C. externa for integrated pest management programs, this study was performed in order to learn about the biological aspects of C. externa fed on Melanaphis sacchari (Zehntner, 1897) (Hemiptera: Aphididae), an invasive pest considered one of the aphid species of greatest economic importance on the world (ElSayed 2013; Peña-Martínez et al. 2015) and recently introduced to Mexico (SENASICA 2014).

\section{Materials and methods}

All experiments were performed in the Entomophagous Insect laboratory of the Centro Nacional de Referencia de Control Biológico (IE-CNRCB) (18 55”3452”N $103^{\circ} 5301.95$ ”W under conditions of $25 \pm 2{ }^{\circ} \mathrm{C}, 60-70 \% \mathrm{R}$. H. and $14: 10 \mathrm{~h}$ L:D cycle.

Insect sources. $C$. externa and $M$. sacchari were collected in sorghum fields in the village of Tecuanillo in the municipality of Tecomán, Colima, México (1851’30.37’N 1035252.03'W); 15 masl). Prior to the biological study, chrysopids were identified based on morphological characteristics (Brooks 1994). Aphids were identified using molecular analysis through the extraction of genomic DNA using the DNeasy ${ }^{\circledR}$ Blood and Tissue $\left(\mathrm{QIAGEN}^{\odot}\right.$ 2006). Specimens were kept at the Colección de Insectos Entomófagos del Centro Nacional de Referencia de Control Biológico, Tecomán Colima, México.

A colony of $C$. externa, feeding on $M$. sacchari was established in the department of IE-CNRCB. The second generation was used to carry out the subsequent experiments.

The aphids were reared on Sorghum vulgare L. plants in 5 $\mathrm{L}$ pots and placed in the CNRCB greenhouses.

Development and survival of Chrysoperla externa. The study started with a cohort of 135 C. externa eggs under $24 \mathrm{~h}$ old. They were placed in groups of 10 in $5 \mathrm{~cm}$ diameter Petri dishes and covered them with damp filter paper in order to prevent drying and mortality. The incubation period from egg laying to the emergence of larva 1 was recorded.

In order to monitor the larval stage, the recently emerged larvae were transferred individually to Petri dishes with a daily average of $50 \mathrm{M}$. sacchari nymphs as food. As a feeding substrate for the aphids, at the bottom of the dish, it was placed $5 \mathrm{~cm}$ diameter of a $S$. vulgare leaf. Every $24 \mathrm{~h}$ the density of the nymphs was adjusted, and the leaf of sorgo was changed to a fresh one. The duration of each larval stage was registered according to the size of the larva and the presence of exuviae.

The beginning of the pupa stage was established when the cocoon was observed, and it culminated in the emergence of the adult.

Once the adults emerge, their sex was determined, and they were transferred with entomological tweezers individually to vessels $350 \mathrm{~mL}$. They were monitored until death. In order to facilitate ventilation and keep the adults from escaping, a $4 \mathrm{~cm}$ diameter opening covered with organza cloth was made. On the bottom side of the cup, a $1.5 \mathrm{~cm}$ diameter perforation was made and covered with cotton and moistened daily to provide water to the adults. Inside the cup, a $2 \times 10 \mathrm{~cm}$ impregnated paper piece with an artificial diet composed of honey, beer yeast, pollen, ascorbic acid and spirulina (Palomares-Pérez et al. 2017).

The duration of the biological cycle is presented as mean and standard deviation using the Excel program (Ott 1993). To compare longevity between females and males, a Student's t-test was conducted using the statistical program SAS 9.2 (SAS INSTITUTE 2008).

Reproduction of Chrysoperla externa. 50 pupae were selected and placed them in an $18 \mathrm{~cm}$ diameter, $7 \mathrm{~cm}$ tall dish. It was monitored $24 \mathrm{~h}$ periods, once the adults emerged; they were collected with entomological tweezers and using a stereoscopic microscope to determine sex, according to size and apical form of abdomen. Thirteen both females and males were selected and placed in pairs in $350 \mathrm{~mL}$ styrofoam cups until his death. When a male died, another replaced it. Observations were made every $24 \mathrm{~h}$ to register the start of egg lying, the number of eggs laid per day and mortality of females.

Life table analysis. The life table was studied through groups of individuals (cohorts) born in the same space of time, from birth until death of the last adult (Rabinovich 1980; Begon et al. 1999). A cohort of 163 eggs was analyzed with the methodology described in the biological cycle, specifying for each age interval the following parameters: $X=$ age (days), $\mathrm{Nx}=$ total number of individuals observed at the beginning of each stage or state, $1 \mathrm{x}=$ proportion of survivors at the beginning of the age $(\mathrm{Nx} / \mathrm{N} 0), \mathrm{dx}=$ number of deaths between ages $1 \mathrm{x}$ y $1 \mathrm{x}+1, \mathrm{qx}=$ death rate $(\mathrm{dx} / \mathrm{lx}), \mathrm{K}=$ death force $(\mathrm{K}=$ $\log 10 \mathrm{Nx}-\log 10 \mathrm{Nx}+1)$ and $\mathrm{ex}=$ life expectancy $(\mathrm{Tx} / \mathrm{lx})$.

\section{Results and discussion}

Development and survival. The biological cycle of $C$. externa presented an average duration of $29.5 \pm 6.2 \mathrm{~d}$ from the egg until adult emergence, with a range of 18 to $45 \mathrm{~d}$. Biological cycle may vary by feed type and temperature; Auad et al. (2001) and Giffoni et al. (2007) who have observed the developmental time of $C$. externa tend to be faster at $26^{\circ} \mathrm{C}$ fed Bemisia tabaci (Gennadius, 1889) (Hemiptera: Aleyrodidae) $(26.1 \pm 0.10 \mathrm{~d})$, which is attributed to their generalist feeding behavior.

The eggs hatched on average at $5.1 \pm 0.3 \mathrm{~d}$, data fits with the range of 5 to $6 \mathrm{~d}$ reported by Ribeiro (1988) when using different prey. Similarly, Fonseca et al. (2015), using Rhopalosiphum maidis (Fitch, 1856) (Hemiptera: Aphididae) as food, reported an embryonic period of 3 to $15.1 \mathrm{~d}$. According to the above, it is concluded that depending on the prey and the temperature, the eggs of $C$. externa presents different periods of incubation. The temperature and the nutritional quality of prey are decisive factors in the biological performance of predator insects, altering for instance the developmental time of pre-imaginal stages and reproductive performances of adults (e.g. fecundity, fertility) (Michaud 2005; Cabral et al. 2006; Jalali et al. 2010).

The larval period presented durations of $13.8 \pm 4.5 \mathrm{~d}$, superior to the data from Lima (2004), who reported a period of $10.8 \mathrm{~d}$ fed on Brevicoryne brassicae (L., 1758) (Hemiptera: Aphididae). This difference can be linked to food quality in 
which a shorter life cycle is the result of good nutrition and faster adaptation by the predator (Soffiantini Lira and De Luna Batista 2006).

The pupa state was completed in $10.6 \pm 1.4 \mathrm{~d}$. In the study by Giffoni et al. (2007), average duration of $7.5 \mathrm{~d}$ was found when they were fed on Aphis craccivora (Koch, 1854) (Hemiptera: Aphididae).

Adult longevity was $63.5 \pm 26.7 \mathrm{~d}$ (Table 1). These results are within the average life range of these predators reported by Soffiantini Lira and De Luna Batista (2006).

Out of a total of 86 adults, 50 were females and 36 males; this represents a 1.4:1 sex ratio. The developmental time was slightly longer for females, although the difference was not statistically significant $(\mathrm{F}=1.42 ; \mathrm{Pr}=0.2785)$ (Table 1$)$. Duration of the larval stage with respect to sex did not show a significant difference $(\mathrm{F}=1.09 ; \mathrm{Pr}=0.6153)$ (Table 1).

The survival of the different biological stages indicates full development of $C$. externa fed on M. sacchari, the opposite is reported by Giffoni et al. (2007) and Salamanca Bastidas et al. (2010); they mention that the biological cycle of C. externa is incomplete, and it only reaches the pupal stage when they feed on Aphis nerii (Boyer, 1841) (Hemiptera: Aphididae) and immature states of Neohydatothrips signifer (Priesner, 1932) (Thysanoptera: Thripidae). Giffoni et al. (2007) also refer a wide variation in the biological cycle of $C$. externa feeding on different species of aphids; when it consumes $A$. craccivora and $R$. maidis its biological cycle from egg to adult is 20.7 and $36.8 \mathrm{~d}$, respectively. It is important to remember that insect development, in general, is also affected by laboratory conditions, mainly temperature, relative humidity and exposure to light (McEwen et al. 2001).
Without a doubt, the results of this study show that C. externa is capable of completing its biological cycle by feeding only on $M$. sacchari nymphs. This is important to consider if one seeks to introduce and establish this predator in an area where it is not found naturally.

Reproduction of Chrysoperla externa. The pre-oviposition period to egg laying ranged from 2 to $11 \mathrm{~d}$ with an average of $6.5 \pm 3.1 \mathrm{~d}$, time similar to the reported by Saini and Salto (1999), but longer to the reported by Elkarmi et al. (1987) for other species of the same genus, Chrysoperla rufilabris (Burmeister, 1839) and Chrysoperla carnea (Stephens, 1836) they presented a period of $3 \mathrm{~d}$. In nature, a lengthy period prior to egg laying is a disadvantage for the survival of the species, since adults who have not reproduced yet are exposed longer to their natural enemies (Canard 1981).

The average number of eggs laid per female was $228.3 \pm$ 139.1 , with a range from 39 to 542 . The daily number of eggs laid was $2.8 \pm 0.2$. The longest-lived female lived for $105 \mathrm{~d}$, while the shortest-lived lasted $12 \mathrm{~d}$.

The fertility curve indicates cyclical behavior with a descending trend and maximum production peaks at 15, 45 and $53 \mathrm{~d}$. Subsequently, egg laying decreases constantly until the death of the female (Fig. 1).

In population terms, the fecundity was $m x=168.9$. The net reproduction rate Ro registered a value of 113.2, meaning that population will increase approximately $113 \%$ in generation time $(\mathrm{T})$ of $28.9 \mathrm{~d}$. The intrinsic growth rate $(\mathrm{rm})$ was 0.163 , this means the population would multiply $16.3 \%$ from one unit of time to the next. Finally, the finite reproductive rate $(\lambda)$ of 1.17 indicates that for each chrysopid at any given time,

Table 1. Biological cycle (days) of Chrysoperla externa fed on Melanaphis sacchari at $25 \pm 2{ }^{\circ} \mathrm{C}, 60-70 \% \mathrm{RH}, 14$ light $\mathrm{h}$.

\begin{tabular}{lccccccc}
\hline \multirow{2}{*}{$\begin{array}{l}\text { State and/or } \\
\text { Stage }\end{array}$} & \multicolumn{3}{c}{ Total } & \multicolumn{2}{c}{ Females $(\mathbf{n}=\mathbf{5 0})$} & \multicolumn{2}{c}{ Males $(\mathbf{n}=\mathbf{3 6})$} \\
\cline { 2 - 8 } & $\mathbf{n}^{\mathbf{1}}$ & Mean \pm S.D. ${ }^{2}$ & Range & Mean \pm S.D. ${ }^{2}$ & Range & Mean \pm S.D. ${ }^{2}$ & Range \\
\hline Egg & 135 & $5.1 \pm 0.3$ & $5-6$ & $5.1 \pm 0.2$ & $5-6$ & $5.1 \pm 0.2$ & $5-6$ \\
Larva 1 & 135 & $4.3 \pm 1.4$ & $1-9$ & $4.5 . \pm 1.2$ & $4-9$ & $4.3 \pm 1.0$ & $3-8$ \\
Larva 2 & 111 & $3.2 \pm 1.1$ & $1-7$ & $3.3 \pm 1.1$ & $1-7$ & $3.1 \pm 0.9$ & $3-4$ \\
Larva 3 & 104 & $6.3 \pm 2.0$ & $1-11$ & $6.2 \pm 1.9$ & $3-10$ & $6.4 \pm 2.0$ & $3-10$ \\
Pupa & 100 & $10.6 \pm 1.4$ & $10-12$ & $10.7 \pm 0.9$ & $9-13$ & $10.5 \pm 1.0$ & $8-12$ \\
Adult & 86 & $63.5 \pm 26.7$ & $6-104$ & $65.5 \pm 28.6$ & $6-104$ & $60.8 \pm 24.0$ & $9-97$ \\
\hline
\end{tabular}

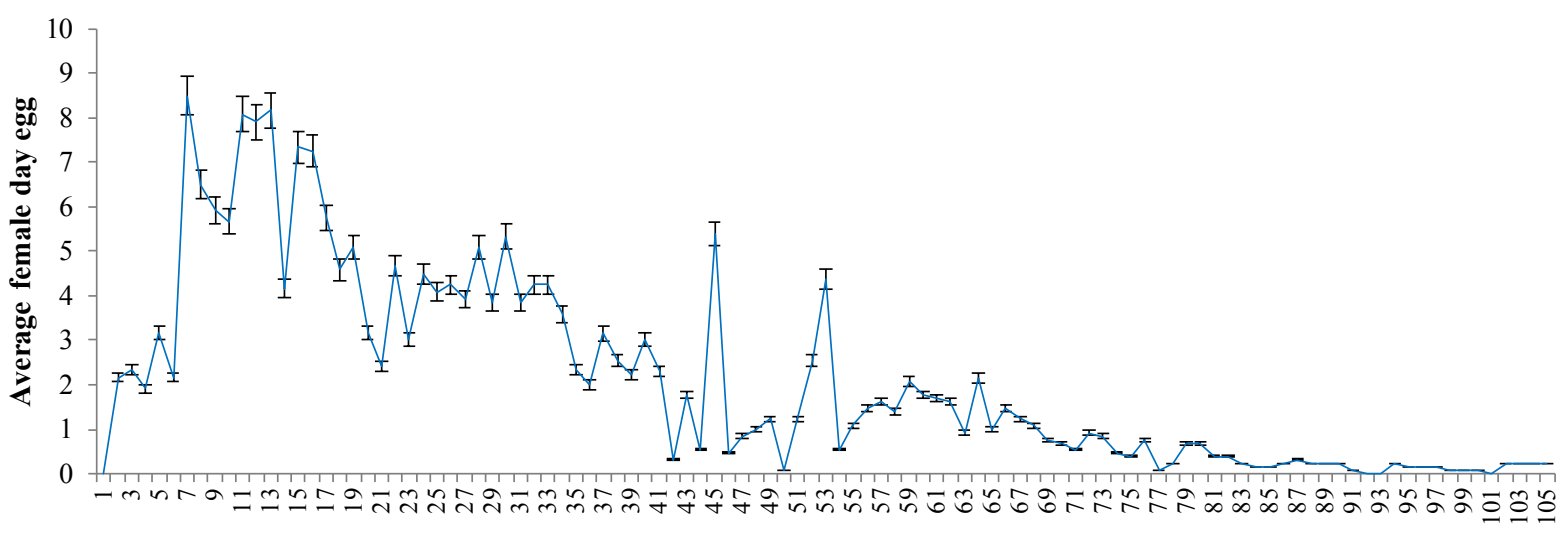

Oviposition days

Figure 1. Eggs oviposited per day by females of Chrysoperla externa fed on Melanaphis sacchari at $25 \pm 2 \mathrm{C} ; 60-70 \% \mathrm{RH} ; 14$ light h. 
Table 2. Horizontal life table (days) of Chrysoperla externa fed on Melanaphis sacchari at $25 \pm 2{ }^{\circ} \mathrm{C}, \quad 60-70 \% \mathrm{RH}, 14$ light $\mathrm{h}$.

\begin{tabular}{lcccccc}
\hline \multicolumn{1}{c}{$\mathbf{X}$} & $\mathbf{N x}$ & $\mathbf{l x}$ & $\mathbf{d x}$ & $\mathbf{q x}$ & $\mathbf{e x}$ & $\mathbf{K}$ \\
\hline Egg & 163 & 1.00 & 28 & 0.17 & 4.00 & 0.08 \\
Larva 1 & 135 & 0.82 & 24 & 0.17 & 3.64 & 0.08 \\
Larva 2 & 111 & 0.68 & 7 & 0.06 & 3.08 & 0.01 \\
Larva 3 & 104 & 0.63 & 4 & 0.03 & 2.20 & 0.01 \\
Pupa & 100 & 0.61 & 14 & 0.14 & 1.86 & 0.07 \\
Adult & 86 & 0.52 & 86 & 1 & 1 & 0.00 \\
\hline
\end{tabular}

$\mathrm{X}=$ biological state; $\mathrm{Nx}=$ number of individuals; $\mathrm{lx}=$ proportion of survivors; $\mathrm{dx}=$ number of deaths; $q x=$ death rate; $\mathrm{K}=$ mortality force; $\mathrm{ex}=$ life expectancy.

there will be 1.17 individuals in the next time unit. Without a doubt, these results show the reproductive and colony establishment potential of C. externa is possible when it feeds on $M$. sacchari.

Life table analysis. The population parameters of cohort table showed that specific death rate (qx) maintains high values in the egg stage $(0.17)$. This is reflected in mortality intensity (K) (0.08) (Table 2).

Both the egg stage and the first larval stages showed a higher mortality (qx) (Table 2). This data suggests a type III survival curve (Southwood 1978; Rabinovich 1980), which indicates a high mortality rate in the early stage of $C$. externa.

In the evaluated population, 86 individuals reached the adult stage (Table 2), it means that $63.7 \%$ of insects handled complete their development, more than the reported by Salamanca Bastidas et al. (2010), who indicate that only $30 \%$ of $C$. externa individuals complete their cycle when they feed on $R$. maidis.

The greatest viability was registered in larva $3(96.2 \%)$, this is important when considering that this stage is the most voracious and therefore the most predatory. Carvalho et al. (1998) and Figueira et al. (2000) report inferior viability in larva 3 when they are fed on eggs of Alabama argillacea (Hübner, 1823) (Lepidoptera: Noctuidae) (90\%) and nymphs of Schizaphis graminum (Rondani, 1852) (Hemiptera: Aphididae) $(70 \%)$.

\section{Conclusions}

The $63.7 \%$ of insects completed their biological cycle; therefore, it is concluded that $M$. sacchari satisfies the necessary nutritional requirements to complete the four biological stages of C. externa. The net reproduction rate Ro, the intrinsic growth rate $(\mathrm{rm})$ and the finite reproduction rate $(\lambda)$ show the reproductive potential of $C$. externa when is fed on M. sacchari.

\section{Acknowledgements}

We thank Dra. Beatriz Rodríguez Velez for reviewing the English version of this manuscript.

\section{Literatura cited}

AUAD, A. M.; TOSCANO, L. C.; BOIÇA JÚNIOR, A. L.; DE FREITAS, S. 2001. Aspectos biológicos dos estádios imaturos de Chrysoperla externa (Hagen) e Ceraeochrysa cincta (Schneider) (Neuroptera: Chrysopidae) alimentados com ovos e ninfas de Bemisia tabaci (Gennadius) biótipo B (Hemiptera: Aleyrodidae). Neotropical Entomology 30 (3): 429-432. https:// doi.org/10.1590/S1519-566X2001000300015

BROOKS, S. J. 1994. A taxonomic review of the common green lacewing genus Chrysoperla (Neuroptera: Chrysopidae). Bulletin of the British Museum of Natural History, Entomology Series 63 (2): 137-210.

BEGON, M.; HARPER, J. I.; TOWNSEND, C. R. 1999. Ecología: individuos, poblaciones y comunidades. Editorial Omega S.A, Barcelona, Spain. 1148 p.

CABRAL, S.; SOARES, A. O.; MOURA, R.; GARCIA, P. 2006. Suitability of Aphis fabae, Myzus persicae (Homoptera: Aphididae) and Aleyrodes proletella (Homoptera: Aleyrodidae) as prey for Coccinella undecimpunctata (Coleoptera: Coccinellidae). Biological Control 39 (3): 434-440. https://doi. org/10.1016/j.biocontrol.2006.08.008

CANARD, M. 1981. Chrysopes (Neuroptera) peu connues ou nouvelles pour la France. Neuroptera International 1 (3): 99109.

CARDOSO, J. T.; LAZZARI, S. M. N. 2003. Development and consumption capacity of Chrysoperla externa (Hagen) (Neuroptera, Chrysopidae) fed with Cinara spp. (Hemiptera: Aphididae) under three temperatures. Revista Brasileira de Zoologia 20 (4): 573-576. https://doi.org/10.1590/S010181752003000400002

CARVALHO, C. F.; SOUZA, B.; SANTOS, T. M. 1998. Predation capacity and reproduction potential of Chrysoperla externa (Hagen) (Neuroptera: Chrysopidae) fed on Alabama argillacea (Hübner) eggs. Acta Zoologica Fennica 209: 83-86.

CHANG, Y. F.; TAUBER, M. J.; TAUBER, C. A.; NYROP, J. P. 2000. Interpopulation variation in Chrysoperla carnea reproduction: implications for mass-rearing and storage. Entomologia Experimentalis et Applicata 95 (3): 293-302. https://doi.org/10.1046/j.1570-7458.2000.00668.x

ELKARMI, L. A.; HARRIS, M. K.; MORRISON, R. K. 1987. Laboratory rearing of Chrysoperla rufilabris (Burmeister), a predator of insect pests of pecans. Southwestern Entomologist 12 (1): 73-78.

ELSAYED, A. I. 2013. Maize (Zea mays L.) constitutes a novel host to Sugarcane yellow leaf virus. Canadian Journal of Plant Pathology 35 (1): 68-74. https://doi.org/10.1080/07060661.201 2.758177

FIGUEIRA, L. K.; CARVALHO, C. F.; SOUZA, B. 2000. Biologia e exigências térmicas de Chrysoperla externa (Hagen, 1861) (Neuroptera: Chrysopidae) alimentada com ovos de Alabama argillacea (Hübner, 1818) (Lepidoptera: Noctuidae). Ciência e Agrotecnologia 24 (2): 319-326.

FONSECA, A. R.; CARVALHO, C. F.; CRUZ, I.; SOUZA, B.; ECOLE, C. C. 2015. Development and predatory capacity of Chrysoperla externa (Neuroptera: Chrysopidae) larvae at different temperatures. Revista Colombiana de Entomología 41 (1): 5-11.

GIFFONI, J.; VALERA, N.; DÍAZ, F.; VÁSQUEZ, C. 2007. Ciclo biológico de Chrysoperla externa (Hagen) (Neuroptera: Chrysopidae) alimentada con diferentes presas. Bioagro 19 (2): 109-113.

GITIRANA, J.; CARVALHO, C. F.; SOUZA, B.; SANTA, L. V. 2001. Fluctuação populacional de especies de Ceraeochrysa Adams, 1882 (Neuroptera: Chrysopidae) en citros na região de Lavras - MG. Ciência e Agrotecnologia 25 (3): 550-559.

GUARÍN, J. H. 2003. Thrips palmi Karny en el oriente antioqueño. Biología, efecto de hongos entomopatógenos y de extractos vegetales, comportamiento de sus enemigos naturales en campo e impacto ambiental para su manejo sostenible. Rionegro, Antioquia (Colombia). Editorial: Gráficas Madrigal. 60 p.

JALALI, M. A.; TIRRY, L.; DE CLERCQ, P. 2010. Effect of temperature on the functional response of Adalia bipunctata to Myzus persicae. BioControl 55: 261-269. https://doi. org/10.1007/s10526-009-9237-6 
LIMA, A. K. V. de O. 2004. Biologia e capacidade de predação de Chrysoperla externa (Neuroptera: Chrysopidae) em Areia. Monografia (Para grau de Engenheiro Agrônomo). Centro de ciências agrárias, Universidade Federal da Paraíba campus II, Areia, PB. 19 p. Citado en: Soffiantini Lira, R.; De Luna Batista, J. 2006. Aspectos biológicos de Chrysoperla externa alimentados com pulgões da erva-doce. Revista de Biologia e Ciências da Terra, Bioterra 6 (2): 20-35.

LOERA, J.; VARGAS, J.; LÓPEZ, J.; REYES, M. 2001. Uso y manejo de Chrysoperla carnea. Citado en: Castro L., M. A.; Martínez O., J. W.; Dotor R., M. Y. 2016. Evaluación del efecto regulador de Chrysoperla externa sobre mosca blanca Trialeurodes vaporariorum en tomate. Revista de Ciencias Agrícolas 33 (2): 43-54. http://dx.doi.org/10.22267rcia.163302.51

McEWEN, P. K.; NEW, T. R.; WHITTINGTON, A. E. 2001. Lacewings in the crop environment. Cambridge University Press. Cambridge 546 p. https://doi.org/10.1017/CBO9780511666117

MICHAUD, J. P. 2005. On the assessment of prey suitability in aphidophagous Coccinelidae. European Journal of Entomology 102 (3): 385-390. https://doi.org/10.14411/eje.2005.055

MILLER, G. L.; OSWALD, J. D.; MILLER, D. R. 2004. Lacewings and scale insects: a review of predator/prey associations between the Neuropterida and Coccoidea (Insecta: Neuroptera, Raphidioptera, Hemiptera). Annals of the Entomological Society of America 97 (6): 1103-1125. https:// doi.org/10.1603/0013-8746(2004)097[1103:LASIAR]2.0. $\mathrm{CO} ; 2$

OTT, R. L. 1993. An introduction to statistical methods and data analysis, (4th ed.). Duxbury Press, Belmont, California, EE. UU. $1051 \mathrm{p}$.

PALOMARES-PÉREZ， M.; BARAJAS-ROMERO, M. I.; ARREDONDO-BERNAL, H. C. 2017. Producción masiva de Ceraeochrysa valida (Banks) (Neuroptera: Chrysopidae) a 30 ${ }^{\circ} \mathrm{C}$. Chilean Journal of Agricultural and Animal Sciences 33 (2): 187-191. https://doi.org/10.4067/S0719-38902017005000504

PEÑA-MARTÍNEZ，R.; MUÑOZ-VIVEROS，A. L.; RAMOSESPINOSA, M. G.; TERRÓN-SIERRA, R. 2015. Listado de plantas hospedantes del complejo Melanaphis sacchari/sorghi (Hemiptera: Aphididae), registros internacionales y potenciales en México. Entomología Mexicana 2: 582-587.

RABINOVICH, J. 1980. Introducción a la ecología de poblaciones animales. Editorial Continental 1 S.A., Mexico. 313 p.

QIAGEN $^{\circ}$. 2006. DNeasy ${ }^{\circledR}$ Blood and tissue handbook. Available in: https://www.qiagen.com/us/ [Review data: 5 Jun 2016].

RIBEIRO, M. J. 1988. Biologia de Chrysoperla externa (Hagen, 1861) (Neuroptera: Chrysopidae) alimentada com diferentes dietas. Dissertação (Mestrado em Fitossanidade), Escola Superior de Agricultura de Lavras, Lavras. 131 p.
SAINI, E.; SALTO, C. 1999. Desarrollo de Chrysoperla externa (Neuroptera: Chrysopidae) con diferentes regímenes alimentarios larvales. Revista de la Sociedad Entomológica Argentina 58 (34): 85-89.

SALAMANCA BASTIDAS, J.; VARÓN DEVIA, E. H.; SANTOS AMAYA, O. 2010. Cría y evaluación de la capacidad de depredación de Chrysoperla externa sobre Neohydatothrips signifer, trips plaga del cultivo de maracuyá. Corpoica Ciencia y Tecnología Agropecuaria 11 (1) 31-40. https://doi.org/10.21930/ reta.vol11 num1 art:192

SAS INSTITUTE. 2008. Users Guide: Statistics version 9.02 for Windows. SAS Institute Inc., Cary, North Carolina, EE. UU.

SENASICA. 2014. Pulgón amarillo Melanaphis sacchari (Zehntner). Ficha técnica No. 43. SAGARPA. México. Available in: https:// www.google.com/url? sa $=$ t\& $r c t=j \& q=\&$ esrc $=$ s\&source $=$ web\&c $\mathrm{d}=\&$ ved=2ahUKEwi4opWuiuTqAhWBm-AKHYhPDZYQFjA AegQIAxAB\&url=http\%3A\%2F\%2Fwww.cesavep.org\%2Fdes cargas\%2FSORGO\%2FFichaT\%25C3\%25A9cnicaNo.43Pulgo namarillo 25junio.pdf\&usg=AOvVaw2vofmAH492D5yDD5Z mJ3E5. [Review data: 30 May 2016].

SOFFIANTINI LIRA, R.; DE LUNA BATISTA, J. 2006. Aspectos biológicos de Chrysoperla externa alimentados com pulgões da erva-doce. Revista de Biologia e Ciências da Terra, Bioterra 6 (2): $20-35$.

SOUTHWOOD, T. R. E. 1978. Ecological methods: With particular reference to the study of insect populations. Second Edition. Chapman and Hall, Nueva York, USA. 524 p.

VELÁZQUEZ-GRISALES, L. P. 2004. Estudio de la biología de Ceraeochrysa claveri (Neuroptera: Chrysopidae) alimentada con dos tipos de presas en condiciones de laboratorio. Informe Científico. Centro Internacional de Agricultura Tropical y Universidad de Caldas. Facultad Ciencias Agropecuarias. Manizales (Colombia). 35 p.

\section{Origin and funding}

Centro Nacional de Referencia de Control Biológico, $\mathrm{km} \mathrm{1,5}$ Carretera Tecomán-Estación FFCC, Colonia Tepeyac, Colima, México, C. P. 28110.

\section{Author contribution}

Martín Palomares-Pérez: Information, analysis and writing. Teresa de Jesús Molina-Ruelas: Data collection.

Manuel Bravo-Núñez: Data Collection.

Hugo Cesar Arredondo-Bernal: Suggestions, writing review and approval of the study. 